\title{
Olive Twig and Branch Dieback in California Caused by Cytospora oleicola and the Newly Described Species Cytospora olivarum sp. nov.
}

\author{
José Ramón Úrbez-Torres, ${ }^{1, \dagger}$ Daniel P. Lawrence, ${ }^{2}$ Francesca Peduto Hand, ${ }^{3}$ and Florent P. Trouillas ${ }^{4, \dagger}$ \\ ${ }^{1}$ Agriculture and Agri-Food Canada, Summerland Research and Development Centre, Summerland, BC V0H 1Z0, Canada \\ ${ }^{2}$ Department of Plant Pathology, University of California, Davis, CA 95616, U.S.A. \\ ${ }^{3}$ Department of Plant Pathology, Ohio State University, Columbus, OH 43210, U.S.A. \\ ${ }^{4}$ Department of Plant Pathology, University of California, Davis and Kearney Agricultural Research and Extension Centre, \\ Parlier, CA 93648, U.S.A.
}

\begin{abstract}
Field surveys conducted throughout California olive-growing regions in 2008 and 2009 resulted in a collection of 101 Cytospora-like isolates from olive twig and branch dieback symptoms. Cytospora isolates were isolated from multiple cvs. in different olive orchards in Fresno, Madera, Merced, Napa, Riverside, Santa Barbara, Sonoma, Tulare, and Ventura counties. Taxonomic studies of macro- and microscopic structures along with multigene phylogenetic analyses of

oleicola and C. olivarum sp. nov. Pathogenicity studies conducted in mature olive trees cvs. Manzanillo and Sevillano showed both species to be pathogenic and able to cause vascular necrosis and cankers in olive branches. This study adds to the current knowledge on the etiology of olive twig and branch dieback and provides new important information for the development of effective control strategies against canker diseases affecting olive in California.
\end{abstract} the internal transcribed spacer region, including the 5.8S rDNA (ITS1-5.8S-ITS2), and fragments of the translation elongation factor $1-\alpha$, beta-tubulin, and actin genes identified two species, Cytospora
Keywords: fungi, fruit, etiology, pathogen detection, olive, dieback, phylogenetics
During the last decade, plantings and production of European olive (Olea europaea L.) have increased globally by about 20 and $10 \%$, respectively. Currently, with approximately 11 million ha cultivated and 21 million tons harvested in 2017, olive is one of the most planted tree crops worldwide (www.fao.org/faostat/en/\#data/QC). This significant increase follows the introduction of super-highdensity (SHD) oil olive production farming (1,500 to 2,500 trees/ ha) with new varieties adapted for mechanized harvest and pruning to reduce production costs (Tous et al. 2011; Vossen 2007). California-grown olives comprise most of the U.S. olive production and have traditionally included mainly table olives in low-density orchards (up to 500 trees/ha). Although the olive acreage has remained stable in California for decades (around 14,000 ha), oil olive production has recently surpassed table olive production. The increase in oil olive production in California is thought to be a response to a steady increase in domestic olive oil consumption due to the apparent health benefits of a Mediterranean diet, the high-quality standards of California olive oil, and the introduction of cost-effective SHD production system (Lazicki and Geisseler 2016).

Olive trees can be afflicted severely by fungal diseases, causing substantial economic losses and eventually limiting the areas of production (Molina de la Rosa et al. 2017; Teviotdale 2005). Although poorly studied, olive canker diseases can be of significant importance. Symptoms of these diseases are characterized by the presence of perennial cankers and vascular necrosis, which cause the decline and eventual death of branches, twigs, and trunks (Fig. 1). Cankercausing fungi infect olive trees primarily through pruning wounds,

${ }^{\dagger}$ Corresponding authors: J. R. Úrbez-Torres, joseramon.urbeztorres@canada.ca; and F. P. Trouillas, flotrouillas@ucdavis.edu

Funding: This research was partially funded by grants from the California Olive Board.

The author(s) declare no conflict of interest.

Accepted for publication 11 February 2020.

(C) 2020 The American Phytopathological Society although olive knot galls or sunburned areas on branches and/or trunks are possible infection courts (Úrbez-Torres et al. 2013). Twigs and shoots can be infected by multiple, distantly related fungal pathogens, causing their decline and eventual death (Úrbez-Torres et al. 2013). Cankers in branches can limit the movement of water through the vascular system, thus causing branches to die back over time. Olive twig and branch dieback can affect one to a few branches or the entire tree. Affected trees become less productive over time, which can result in unsustainable economic losses in highly affected orchards.

To date, several studies have investigated the etiology of olive branch and twig dieback from various olive-growing regions. Early studies conducted in Greece between the late 1970s and early 1990s identified Phoma incompta (Malathrakis 1979), Cytospora oleina (Rumbos 1988), and Eutypa lata (Rumbos 1993) as causal agents of olive branch dieback. Since the early 2000 s, several fungal species primarily in the Botryosphaeriaceae and the Diatrypaceae families have been reported to cause cankers and subsequent dieback in olive trees in different olive-growing regions of the Mediterranean basin (Chattaoui et al. 2011; Kaliterna et al. 2012; Moral et al. 2010; Romero et al. 2005; Taylor et al. 2001; Tosi and Natalini 2009). In California, dieback symptoms have long been known to occur in the field (Schroth and Osgood 1971); however, canker diseases have only been investigated recently. Moral et al. (2010) identified Diplodia seriata and Neofusicoccum mediterraneum (Botryosphaeriaceae) from olive trees afflicted with twig dieback in Glenn, Fresno, and Madera counties. Úrbez-Torres et al. (2013) reported 18 species in the fungal genera Botryosphaeria, Diaporthe, Diatrype, Diplodia, Dothiorella, Eutypa, Lasiodiplodia, Neofusicoccum, Phaeoacremonium, Phaeomoniella, Schizophyllum, and Trametes associated with cankers and olive twig and branch dieback in California. Recently, Trouillas et al. (2019) revealed that Neofabraea kienholzii and Phlyctema vagabunda were responsible for leaf and shoot lesions as well as cankers and shoot dieback of olive in SHD orchards in California.

Species of Cytospora include endophytes, saprophytes, and pathogens of a broad range of woody plants (Adams et al. 2005, 2006; Bills 1996). Since the genus Cytospora was introduced in 1818, over 600 species have been described (http://www.indexfungorum.org/ Names/Names.asp). Currently, 110 species are accepted (Kirk et al. 2008). However, only 45 DNA sequences from type specimens 
are available in GenBank. The large number of Cytospora spp. and the difficulty in discriminating among them phenotypically makes identification to the species level based solely on morphological characters challenging. This is due in part to the important overlap and plasticity of macro- and microscopic structures. Modern studies have used multilocus phylogenetic approaches to discriminate among Cytospora spp. Recently, Lawrence et al. (2018) suggested that translation elongation factor 1- $\alpha$ (TEF1) was the most informative locus for discrimination of Cytospora spp. followed by actin (ACT1), internal transcribed spacer (ITS), and beta-tubulin (TUB2).

Diseases associated with Cytospora spp. have been referred traditionally as Cytospora-, Leucostoma-, Perennial-, or Valsa canker and affect over 85 perennial host plants (Adams et al. 2005, 2006; Lawrence et al. 2017). Symptoms associated with these diseases typically
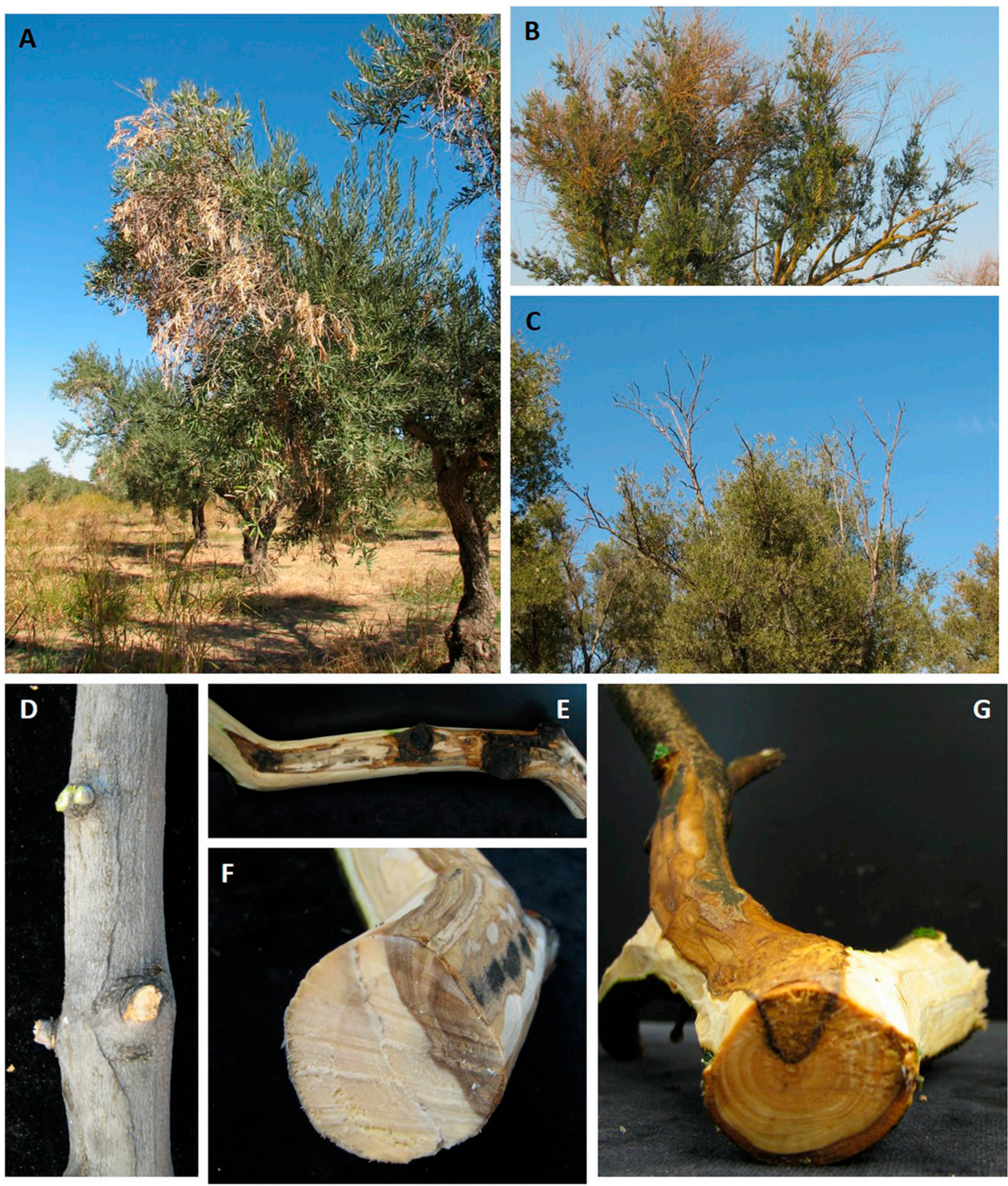

Fig. 1. Characteristic olive dieback symptoms associated with fungal pathogens in olive trees in California. A, Early twig dieback symptoms in a 'Manzanillo' olive tree in Merced County. Dry and yellowish leaves can be observed in affected twigs. B, Severe twig dieback in a 'Manzanillo' olive tree in Fresno County. Leaves have fallen from infected twigs. C, Severe branch dieback in a 'Sevillano' tree in Ventura County. D, Flat and sunken areas of a canker can be observed on infected branches. E and F, Perennial canker developing in an olive branch. G, Wedge-shaped perennial canker progressing into the trunk from a branch infection. 
include sunken lesions on branches and twig dieback. Cytospora diseases can be highly destructive in stone and pome fruit trees and nut trees (Lawrence et al. 2018; Trouillas et al. 2012). Species of Cytospora also have been reported to cause cankers, dieback, and tree death on introduced and/or native forest trees such as Eucalyptus, Populus, and Salix spp. (Adams et al. 2005, 2006; Lawrence et al. 2018). Despite several Cytospora spp. known to cause cankers in woody perennials, there is a lack of knowledge about the diversity and biology of Cytospora spp. affecting olive. The study conducted by Úrbez-Torres et al. (2013) in California between 2008 and 2009 resulted in the collection of 101 Cytospora-like isolates from olive cankers and twig dieback samples. However, complete morphological and molecular characterization of these isolates was not conducted. Therefore, the role that Cytospora played on olive dieback was not included in the study. Accordingly, the main objective of this study was to identify and characterize the Cytospora-like strains collected by Úrbez-Torres et al. (2013) between 2008 and 2009 by means of morphological, molecular, and pathogenicity studies.

\section{Materials and Methods}

Fungal isolates and morphological characterization. A total of 101 Cytospora-like isolates were obtained from field surveys conducted throughout the main olive production areas in California, including the Sacramento Valley, north and central coasts, San Joaquin Valley, and southern California between October 2008 and September 2009 as part of a larger study, which aimed to elucidate the causal agents of olive twig and branch dieback in the state (Úrbez-Torres et al. 2013). Eighty-eight isolates were then putatively identified as Cytospora sp. group one (white mycelium with uneven margin) and 13 isolates as group two (dark mycelium with even margin) based on colony morphologies observed and stored as mycelium plugs in glass vials (20 plugs/vial) at $4^{\circ} \mathrm{C}$ in the fungal culture collection of the Department of Plant Pathology, University of California, Davis, U.S.A.

For the purpose of this study, two isolates representing each group one (UCD465-Oe and UCD474-Oe) and group two (UCD634-Oe and UCD644-Oe) were retrieved from the collection and selected for morphological characterization by transferring five mycelium plugs of each isolate to $85 \mathrm{~mm}$-diameter Petri dishes containing $4 \%$ potato dextrose agar (PDA) (DIFCO, Detroit, MI) amended with tetracycline hydrochloride $(0.01 \%)$ (SIGMA-ALDRICH, St. Louis, MO) (PDAtet). Petri plates were incubated at ambient laboratory light and temperature conditions $\left(24 \pm 2^{\circ} \mathrm{C}\right)$ until fungal colonies were observed. Pure fungal colonies were then transferred to fresh PDA-tet to be used in morphological studies. After 3 to 4 weeks incubation, mycelial plugs ( $5 \mathrm{~mm}$ diameter) from selected isolates were taken from the margin of actively growing colonies and transferred in triplicate into

Table 1. Fungal isolates used in this study and GenBank accession numbers

\begin{tabular}{|c|c|c|c|c|c|c|c|}
\hline \multirow[b]{2}{*}{ Species } & \multirow[b]{2}{*}{ Isolate $^{\mathbf{a}}$} & \multirow[b]{2}{*}{ Host } & \multirow[b]{2}{*}{ Geographic origin } & \multicolumn{4}{|c|}{ GenBank accession $^{\mathbf{b}}$} \\
\hline & & & & ITS & $A C T 1^{\mathrm{c}}$ & TEF1 & $T U B 2^{c}$ \\
\hline Cytospora amydgali & CBS 144233 & Prunus dulcis & Yolo Co., CA, U.S.A. & MG971853 & MG972002 & MG971659 & $\overline{\text { MG971718 }}$ \\
\hline C. amydgali & LH356 & Prunus dulcis & Yolo Co., CA, U.S.A. & MG971852 & MG972001 & MG971658 & MG971717 \\
\hline C. atrocirrhata & CFCC 89615 & Jugulans regia & Xining, Qinghai, China & KF225610 & - & - & - \\
\hline C. berberidis & CFCC 89927 & Berberis dasystachyum & Qinghai Province, China & KP340985 & - & - & - \\
\hline C. californica & CBS 144234 & Juglans regia & Lake Co., CA, U.S.A. & MG971935 & MG972083 & MG971645 & - \\
\hline C. californica & KARE1377 & Prunus dulcis & Glenn Co., CA, U.S.A. & MG971933 & MG972057 & MG971643 & MG971787 \\
\hline C. cedri & CBS 196.50 & Unknown host & Italy & AF192311 & - & JX438575 & - \\
\hline C. chrysosperma & CFCC 89619 & Juglans regia & $\begin{array}{l}\text { Yinchuan, Ningxia, } \\
\text { China }\end{array}$ & KF225614 & KF498677 & - & - \\
\hline C. chrysosperma & CBS 144242 & Camellia sp. & Fresno Co., CA, U.S.A. & MG971892 & MG972041 & MG971602 & MG971758 \\
\hline C. cincta & LP47 & Prunus armeniaca & Michigan, U.S.A. & AF191169 & - & - & - \\
\hline C. donetzica & MFLUCC 16-0574 & Rosa sp. & Russia & KY417731 & KY417697 & - & - \\
\hline C. eriobotryae & IMI 136523 & Eriobotrya japonica & Saharanpur, India & AY347327 & - & - & - \\
\hline C. erumpens & MFLUCC 16-0580 & Salix $\times$ fragilis & Russia & KY417733 & KY417699 & - & - \\
\hline C. eucalypti & CBS 144241 & Prunus dulcis & Merced Co., CA, U.S.A. & MG971907 & MG972056 & MG971617 & MG971772 \\
\hline C. eucalypti & CBS 116815 & Sequoia sempervirens & California, U.S.A. & AY347340 & - & - & - \\
\hline C. gigalocus & HMBF155 & Juglans regia & Xining, Qinghai, China & KF225609 & - & - & - \\
\hline C. granati & CBS 144237 & Punica granatum & Tulare Co., CA, U.S.A. & MG971799 & MG971949 & MG971514 & MG971664 \\
\hline C. joaquinensis & CBS 144235 & Populus deltoides & $\begin{array}{l}\text { San Joaquin Co., CA, } \\
\text { U.S.A. }\end{array}$ & MG971895 & MG972044 & MG971605 & MG971761 \\
\hline C. joaquinensis & 9E-95 & Juglans regia & Tulare Co., CA, U.S.A. & MG971896 & MG972045 & MG971606 & MG971762 \\
\hline C. leucosperma & CBS 191.42 & Taxus baccata & Switzerland & AY347330 & - & - & - \\
\hline C. longispora & CBS 144236 & Prunus domestica & Glenn Co., CA, U.S.A. & MG971905 & MG972054 & MG971615 & MG971764 \\
\hline C. melnikii & MFLUCC 15-0851 & Malus domestica & Russia & KY417735 & KY417701 & - & - \\
\hline C. myrtagena & HiloTib1 & Tibouchina urvilleana & Hilo, HW, U.S.A. & AY347363 & - & - & - \\
\hline C. oleicola & CBS 144248 & Olea europaea & $\begin{array}{l}\text { San Joaquin Co., CA, } \\
\text { U.S.A. }\end{array}$ & MG971944 & MG972098 & MG971660 & MG971752 \\
\hline C. oleicola & KARE255 & Olea europaea & $\begin{array}{l}\text { Sonoma Co., CA, } \\
\text { U.S.A. }\end{array}$ & MG971890 & MG972039 & MG971600 & MG971756 \\
\hline C. oleicola & KARE256 & Olea europaea & $\begin{array}{l}\text { Sonoma Co., CA, } \\
\text { U.S.A. }\end{array}$ & MG971889 & MG972038 & MG971599 & MG971755 \\
\hline C. oleicola & KARE257 & Olea europaea & $\begin{array}{l}\text { Sonoma Co., CA, } \\
\text { U.S.A. }\end{array}$ & MG971888 & MG972037 & MG971598 & MG971754 \\
\hline C. oleicola & KARE258 & Olea europaea & $\begin{array}{l}\text { Sonoma Co., CA, } \\
\text { U.S.A. }\end{array}$ & MG971887 & MG972036 & MG971597 & MG971753 \\
\hline C. oleicola & UCD380-Oe & Olea europaea & $\begin{array}{l}\text { Riverside Co., CA, } \\
\text { U.S.A. }\end{array}$ & MK514091 & MK509022 & MK509027 & MK509032 \\
\hline C. oleicola & UCD465-Oe & Olea europaea & $\begin{array}{l}\text { Sonoma Co., CA, } \\
\text { U.S.A. }\end{array}$ & MK514092 & MK509023 & MK509028 & MK509033 \\
\hline
\end{tabular}

\footnotetext{
a Isolates in bold represent type specimens. Isolates in italics represent Cytospora isolates from this study.

b Sequences in bold were generated in this study.

c JGI represents sequences that were retrieved from the JGI Mycocosm genome portal.
} 
$85 \mathrm{~mm}$ diameter Petri dishes containing 2\% PDA and incubated in the dark at $25^{\circ} \mathrm{C}$ for 14 days. Radial growth was measured after 7 days by taking two measurements perpendicular to each other. Assessments of colony color (Rayner 1970) and morphology were made after 14 days. Pycnidia were induced on lignified cherry wood embedded in PDA medium following Lawrence et al. (2018). Characterization of the pycnidia $(n=20)$ included the diameter, presence/absence of a conceptacle, and color using a binocular Leica MZ95 dissecting microscope (Leica microsystems CMS, Wetzlar, Germany). Locular arrangements of pycnidia were assessed by transversely sectioning pycnidia by hand with a razor blade and observing as above. Conidial dimensions $(n=30)$ and conidiogenous cells $(n=20)$ were measured at $1,000 \times$ as in Lawrence et al. (2018). Morphological measurements are represented by the mean in the center with minima and maxima in parentheses, respectively, rounded to the nearest half micron in the morphological characterization and taxonomy sections below. Optimal growth temperature for UCD634-Oe was assessed by incubating the isolate as described above on PDA in the dark at temperatures ranging from $5^{\circ} \mathrm{C}$ to $40^{\circ} \mathrm{C}$ in $5^{\circ}$ increments for up to 14 days. Radial growth was measured as above. Triplicate colonies were measured at each temperature. This experiment was repeated once.

DNA extraction, sequencing, and phylogenetic analyses. Total genomic DNA from isolates UCD380-Oe, UCD465-Oe, UCD474Oe, UCD634-Oe, UCD644-Oe, and KARE255 to KARE258 was extracted from fungal mycelium and scraped with a sterile scalpel from the surface of 14 day cultures using the DNeasy Plant Kit (Qiagen, Valencia, CA), following the manufacturer's instructions. All
PCR reactions utilized AccuPower PCR Premix (Bioneer, Alameda, CA) following the manufacturer's instructions. Amplification of the ITS region, including 5.8S rDNA (ITS1-5.8S-ITS2), using the primer set ITS5 and ITS4 followed the protocol of White et al. (1990). Amplification of portions of TEF1 utilized the primer set EF1-688F/1251R (Alves et al. 2008), TUB2 utilized primers Bt1a/ 1b (Glass and Donaldson 1995), and ACT1 utilized primers ACT512F/783R (Carbone and Kohn 1999), with a slightly modified PCR program for TUB2 and ACT1 as in Lawrence et al. (2018).

PCR products were visualized on $1.5 \%$ agarose gels $(120 \mathrm{~V}$ for $25 \mathrm{~min}$ ) stained with GelRed (Biotium, Fremont, CA), following the manufacturer's instructions, to confirm presence and size of PCR products, then purified via Exonuclease I and recombinant Shrimp Alkaline Phosphatase (Affymetrix, Santa Clara, CA), and sequenced in both directions on an ABI 3730 Capillary Electrophoresis Genetic Analyzer (College of Biological Sciences Sequencing Facility, University of California, Davis).

Forward and reverse reads were assembled, proofread, and edited in Sequencher v. 5 (Gene Codes Corporation, Ann Arbor, MI) and deposited in GenBank (Table 1). Sequences with high similarity from ex-type $(n=31)$ and non-type $(n=17)$ Cytospora sequences were included for phylogenetic reference utilizing the BLASTn function in NCBI and literature review (Table 1). Multiple sequence alignments were performed in MEGA v. 6 (Tamura et al. 2013) and adjusted in Mesquite v. 3.10 (Maddison and Maddison 2016). Alignments were deposited in TreeBASE under accession number S23465. The concatenated four-gene dataset was analyzed using

Table 1. (Continued from previous page)

\begin{tabular}{|c|c|c|c|c|c|c|c|}
\hline \multirow[b]{2}{*}{ Species } & \multirow[b]{2}{*}{ Isolate $^{\mathbf{a}}$} & \multirow[b]{2}{*}{ Host } & \multirow[b]{2}{*}{ Geographic origin } & \multicolumn{4}{|c|}{ GenBank accession $^{\mathbf{b}}$} \\
\hline & & & & ITS & $A C T 1^{\mathrm{c}}$ & TEF1 & $T U B 2^{c}$ \\
\hline C. oleicola & UCD474-Oe & Olea europaea & $\begin{array}{l}\text { Sonoma Co., CA, } \\
\text { U.S.A. }\end{array}$ & MK514093 & MK509024 & MK509029 & MK509034 \\
\hline C. olivarum & $\begin{array}{l}\text { UCD634-Oe CBS } \\
145585\end{array}$ & Olea europaea & Ventura Co., CA, U.S.A. & MK514094 & MK509025 & MK509030 & MK509035 \\
\hline C. olivarum & UCD644-Oe & Olea europaea & Ventura Co., CA, U.S.A. & MK514095 & MK509026 & MK509031 & MK509036 \\
\hline C. parapistaciae & CBS 144506 & Pistacia vera & Kern Co., CA, U.S.A. & MG971804 & MG971954 & MG971519 & MG971669 \\
\hline C. parapistaciae & KARE269 & Pistacia vera & Kern Co., CA, U.S.A. & MG971805 & MG971955 & MG971520 & MG971670 \\
\hline C. pistaciae & CBS 144238 & Pistacia vera & Merced Co., CA, U.S.A. & MG971802 & MG971952 & MG971517 & MG971667 \\
\hline C. pistaciae & KARE442 & Pistacia vera & Merced Co., CA, U.S.A. & MG971803 & MG971953 & MG971518 & MG971668 \\
\hline C. plurivora & CBS 144239 & Olea europaea & $\begin{array}{l}\text { San Joaquin Co., CA, } \\
\text { U.S.A. }\end{array}$ & MG971861 & MG972010 & MG971572 & MG971726 \\
\hline C. plurivora & KARE1450 & Prunus dulcis & Kern Co., CA, U.S.A. & MG971860 & MG972009 & MG971571 & MG971725 \\
\hline C. populicola & CBS 144240 & Populus deltoides & $\begin{array}{l}\text { San Joaquin Co., CA, } \\
\text { U.S.A. }\end{array}$ & MG971891 & MG972040 & MG971601 & MG971757 \\
\hline C. pruinopsis & CFCC 50034 & Ulmus pumila & Harbin, China & KP281259 & - & - & - \\
\hline C. 'pruinosa' & CBS 201.42 & Syringa vulgaris & Switzerland & DQ243801 & - & JX438582 & - \\
\hline C. 'pruinosa' & CBS 118555 & Olea europaea v. africana & South Africa & DQ243790 & - & - & - \\
\hline C. 'pruinosa' & PPRI6334 & Olea europaea & South Africa & DQ243789 & - & JX438581 & - \\
\hline C. punicae & CBS 199.50 & Punica granatum & Turkey & JX438622 & - & JX438568 & - \\
\hline C. punicae & CBS 144244 & Punica granatum & Madera Co., CA, U.S.A. & MG971943 & MG972091 & MG971654 & MG971798 \\
\hline C. sacculus & CFCC 89624 & Juglans regia & Gannan, Gansu, China & KF225615 & - & KP310860 & - \\
\hline C. sibiraeae & CFCC 50045 & Sibiraea angustata & Gannan, Gansu, China & KP340987 & - & - & - \\
\hline C. sorbi & MFLUCC 16-0631 & Sorbus aucuparia & Russia & KY417752 & KY417718 & - & - \\
\hline C. sorbicola & MFLUCC 16-0584 & Acer pseudoplatanus & Russia & KY417755 & KY417721 & - & - \\
\hline C. sorbicola & CBS 144245 & Prunus dulcis & $\begin{array}{l}\text { Stanislaus Co., CA, } \\
\text { U.S.A. }\end{array}$ & MG971833 & MG971983 & MG971548 & MG971698 \\
\hline C. valsoidea & CMW 4309 & Eucalyptus grandis & Sumatra, Indonesia & AF192312 & - & - & - \\
\hline C. vinacea & CBS 141585 & $\begin{array}{l}\text { Vitis interspecific hybrid } \\
\text { 'Vidal' }\end{array}$ & New Hampshire, U.S.A. & KX256256 & - & KX256277 & - \\
\hline C. viticola & CBS 141586 & $\begin{array}{l}\text { Vitis vinifera 'Cabernet } \\
\text { Franc' }\end{array}$ & Connecticut, U.S.A. & KX256239 & - & KX256260 & - \\
\hline Diaporthe ampelina & Wolf912 & $\begin{array}{l}\text { Vitis vinifera 'Thompson } \\
\text { seedless' }\end{array}$ & Solano Co., CA, U.S.A. & KM669964 & JGI & KM669820 & JGI \\
\hline Diaporthe benedicti & SBen914 & Salix sp. & $\begin{array}{l}\text { San Benito Co., CA, } \\
\text { U.S.A. }\end{array}$ & KM669929 & - & KM669785 & - \\
\hline $\begin{array}{l}\text { Leucostoma } \\
\text { parapersoonii }\end{array}$ & CBS 116845 & Prunus serotina & Michigan, U.S.A. & AF191181 & - & - & - \\
\hline Valsa sordida & CBS 197.50 & Populus tremula & United Kingdom & AY347322 & - & - & - \\
\hline
\end{tabular}


two different optimality search criteria, maximum parsimony (MP) and maximum likelihood (ML), in PAUP* $4.0 \mathrm{~b} 162$ and GARLI 0.951 (Swofford 1999; Zwickl 2006), respectively. For the MP analysis, a heuristic search with 1,000 random sequence additions was implemented with the Tree-Bisection-Reconnection algorithm; gaps were treated as missing data. Bootstrap analysis with 1,000 replicates was used to estimate branch support. For ML analysis, MEGA was used to determine the best-fit model of nucleotide evolution based on the Akaike Information Criterion (AIC) for each dataset with GARLI using the default parameters and branch support was estimated by 1,000 bootstrap replicates. Sequences of Diaporthe ampelina isolate Wolf912 and D. benedicti isolate SBen914 (Diaporthales, Diaporthaceae) (Lawrence et al. 2015, 2018) served as the outgroup taxa in the phylogenetic analyses.

Pathogenicity tests. Pathogenicity studies were conducted to determine if Cytospora-like isolates obtained from cankers represent important pathogens of olive in California. One representative isolate (UCD465-Oe and UCD634-Oe) from each putative Cytospora spp. was selected. Pathogenicity tests were conducted on mature 'Manzanillo' and 'Sevillano' olive trees located in an experimental orchard at the University of California Nickels Soil Laboratory Field Station in Arbuckle, CA. Two- to three-year-old branches from both cultivars were selected for inoculation. Ten branches per isolate (one branch per tree) and per olive cultivar were used and inoculations were arranged in a completely randomized design. The distal end of each branch was inoculated by placing a 5-mm-diam. mycelium plug, taken from the margin of a 7-day-old actively growing colony on PDA, in a wound created with a sterile 5-mm-diameter cork borer.
Inoculated wounds were then sealed with petroleum jelly and protected with Parafilm (Sigma-Aldrich, St. Louis, MO). The same number of negative control branches were mock inoculated with sterile PDA plugs as above and sealed with petroleum jelly and protected with Parafilm. Samples were collected after 6 months incubation and returned to the laboratory for assessment of disease. Examination of vascular discoloration and reisolation of the inoculated isolates were conducted as described by Úrbez-Torres et al. (2013). Data from the pathogenicity tests were analyzed using SAS (Version 9.1.3; SAS Institute, Cary, NC, U.S.A.). Homogeneity of variance was tested using Levene's test. Difference in length of vascular discoloration caused by each fungal isolate was determined by one-way analysis of variance (ANOVA) within each cv. separately. Treatment means were compared using Fisher's least significant difference (LSD) test at the 5\% significance level. A two-way ANOVA was performed to determine significant differences between 'Manzanillo' and 'Sevillano' olives.

\section{Results}

Morphological characterization. Average colony growth at $25^{\circ} \mathrm{C}$ after 14 days varied between group one isolates (UCD465-Oe and UCD474-Oe) and group two isolates (UCD634-Oe and UCD644Oe). C. oleicola UCD465-Oe and UCD474-Oe produced similar colony diameter averages after 7 days, $55 \mathrm{~mm}$ and $57.3 \mathrm{~mm}$, respectively. C. oleicola UCD474-Oe produced a white to off-white, slow-growing colony with uneven margin expansion, with the center of the colony becoming buff in color by 14 days. Many aggregated, globose, black pycnidia (704.0-) $890.5(-1029.0) \mu \mathrm{m}$ in diameter, with a single
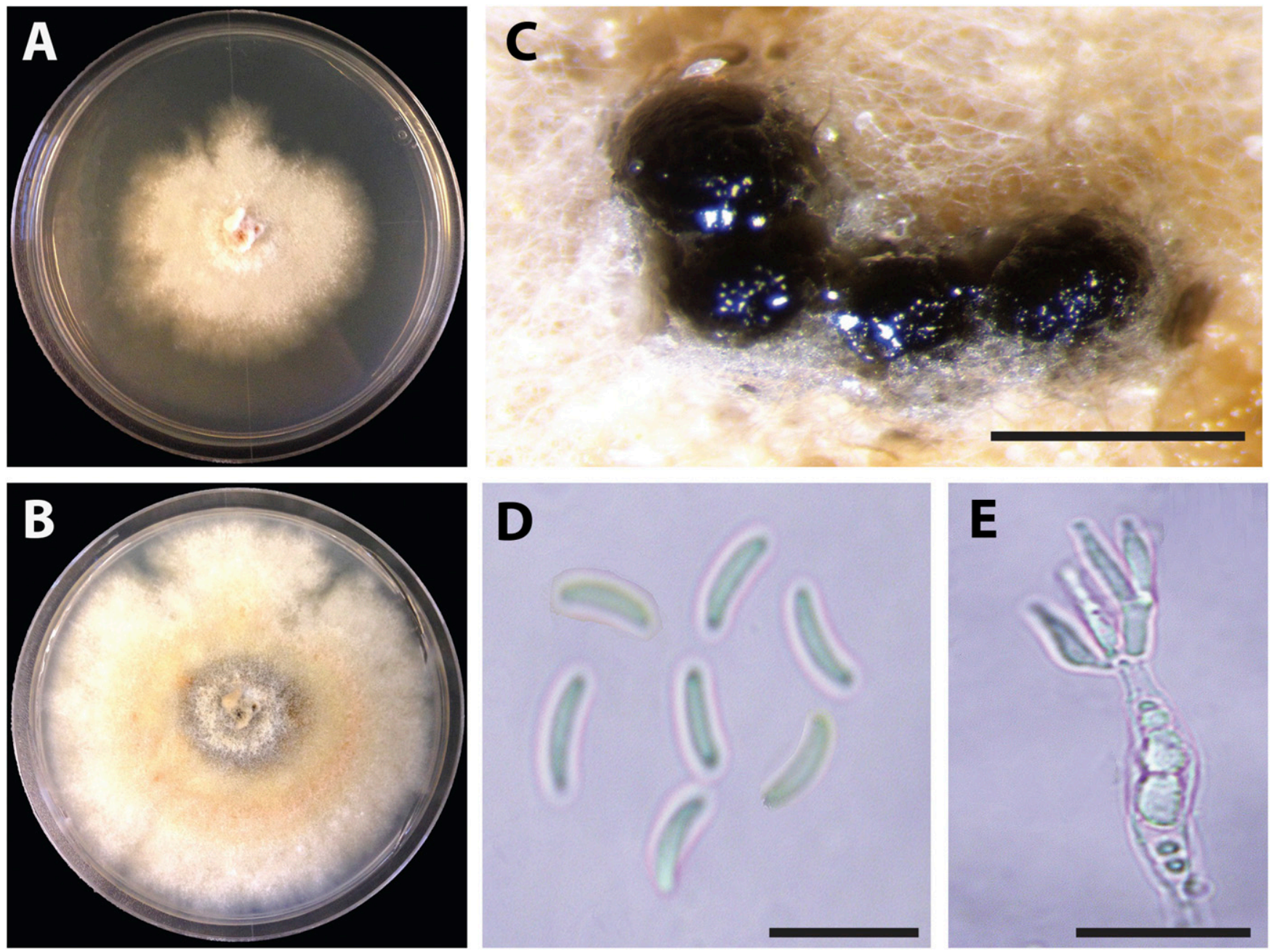

Fig. 2. Morphology of Cytospora oleicola UCD474-Oe. A, Colony cultured on potato dextrose agar at $25^{\circ} \mathrm{C}$ in the dark for 7 days. B, Colony cultured on potato dextrose agar at $25^{\circ} \mathrm{C}$ in the dark for 14 days. C, Pycnidia. D, Conidia. E, Conidiophores and filamentous conidiogenous cells. Scale bars: $1 \mathrm{~mm}(\mathrm{C}), 5 \mu \mathrm{m}(\mathrm{D})$, and $20 \mu \mathrm{m}$ (E). 
internal locule, were produced on autoclaved cherry wood within 7 to 10 days. Conidiophores were straight, reduced to branching filamentous conidiogenous cells (13.0-) $17.0(-27.0) \times(2.5-) 2.5(-3.5) \mu \mathrm{m}$. Conidia were (4.5-) $5.0(-5.5) \times(1.0-) 1.0(-1.5) \mu \mathrm{m}$, abundant, single, hyaline to light brown, eguttulate, aseptate, and allantoid (Fig. 2). Morphological characterization of $C$. olivarum isolates UCD634-Oe and UCD644-Oe is described below.

Taxonomy. Morphological comparisons coupled with the results of the combined four-gene dataset identified the isolates UCD634Oe and UCD644-Oe as a strongly supported lineage for which no apparent species name exists. Therefore, we propose the following new species name to properly circumscribe this unique taxon.

Cytospora olivarum Úrbez-Torr., D.P. Lawr., Peduto, Gubler \& Trouillas sp. nov.

MycoBank No.: MB829695; Figure 3

Typification. U.S.A., California: Ventura County, Piru City area $34^{\circ} 24^{\prime} 26^{\prime \prime} \mathrm{N}, 118^{\circ} 47^{\prime} 59^{\prime \prime} \mathrm{W}, 214 \mathrm{~m}$ a.s.l. isolated from wood canker of Olea europeae cv. Sevillano, April 2009, J.R. Úrbez-Torres No. UCD634-Oe (holotype BPI 910946, dried culture; ex-type CBS 145585).

Etymology. Refers to the epithet, meaning "of the olive trees."

Colony diameter of $C$. olivarum isolate UCD634-Oe (CBS 145585) $65.3 \mathrm{~mm}$ in 7 days at $25^{\circ} \mathrm{C}$ on PDA, medium-growing, at 14 days raised in center, wooly buff colony with raised wooly buff margin. Hyphae hyaline, smooth, straight, branched, and septate. Conidiomata pycnidioid, mostly solitary, sometimes aggregated, dark, globose, white wiry surface hyphae, without conceptacle,
(438.0-) $717.5(-880.0) \mu \mathrm{m}$ in diameter $(n=20)$, with multiple internal locules with shared invaginated walls. Conidiophores reduced to conidiogenous cells, simple, holoblastic, $(7.0-) 8.5(-10.5) \times$ (1.5-) $2.0(-3.0) \mu \mathrm{m}(n=20)$, that are wider at the base and taper toward the apex. Conidia (4.5-) $5.0(-5.5) \times(1.0-) 1.0(-1.5) \mu \mathrm{m}(n=$ 30), abundant, single, hyaline to light brown, eguttulate, aseptate, allantoid. No sexual morph observed. Known distribution: Ventura Co., California, U.S.A.

Other material examined: U.S.A., California: Ventura County, Piru City area $34^{\circ} 24^{\prime} 26^{\prime \prime} \mathrm{N}, 118^{\circ} 47^{\prime} 59^{\prime \prime} \mathrm{W}, 214 \mathrm{~m}$ a.s.l. isolated from wood canker of Olea europeae cv. Sevillano, April 2009, J.R. ÚrbezTorres No. UCD644-Oe.

Phylogenetic analyses. PCR amplification of the ITS region, TEF1, TUB2, and ACT1 generated 524 to 527,558 to 620,537 to 569 , and 282 to 288 bp fragments, respectively. The four-gene (ITS+TEF1+TUB2+ACT1) 59 sequence dataset consisted of 2,346 characters $(1,401$ characters were constant, 215 characters were parsimony-uninformative, and 730 characters were parsimony informative). MP analysis produced 54 equally most parsimonious trees of 2,696 steps and a consistency index (CI), retention index (RI), and rescaled consistency index (RC) of $0.582,0.798$, and 0.464 , respectively. ML analyses utilized the following models of nucleotide evolution based on the AIC; $\mathrm{K} 2+\mathrm{G}+\mathrm{I}$ for both the ACT1 and TEF1, $\mathrm{HKY}+\mathrm{G}$ for $T U B 2$, and $\mathrm{GTR}+\mathrm{G}+\mathrm{I}$ for ITS. MP and ML analyses revealed that Californian Cytospora isolates obtained in this study were divided into two distinct phylogenetic species. Seven isolates representing one morphological group (UCD380-Oe, UCD465-Oe,
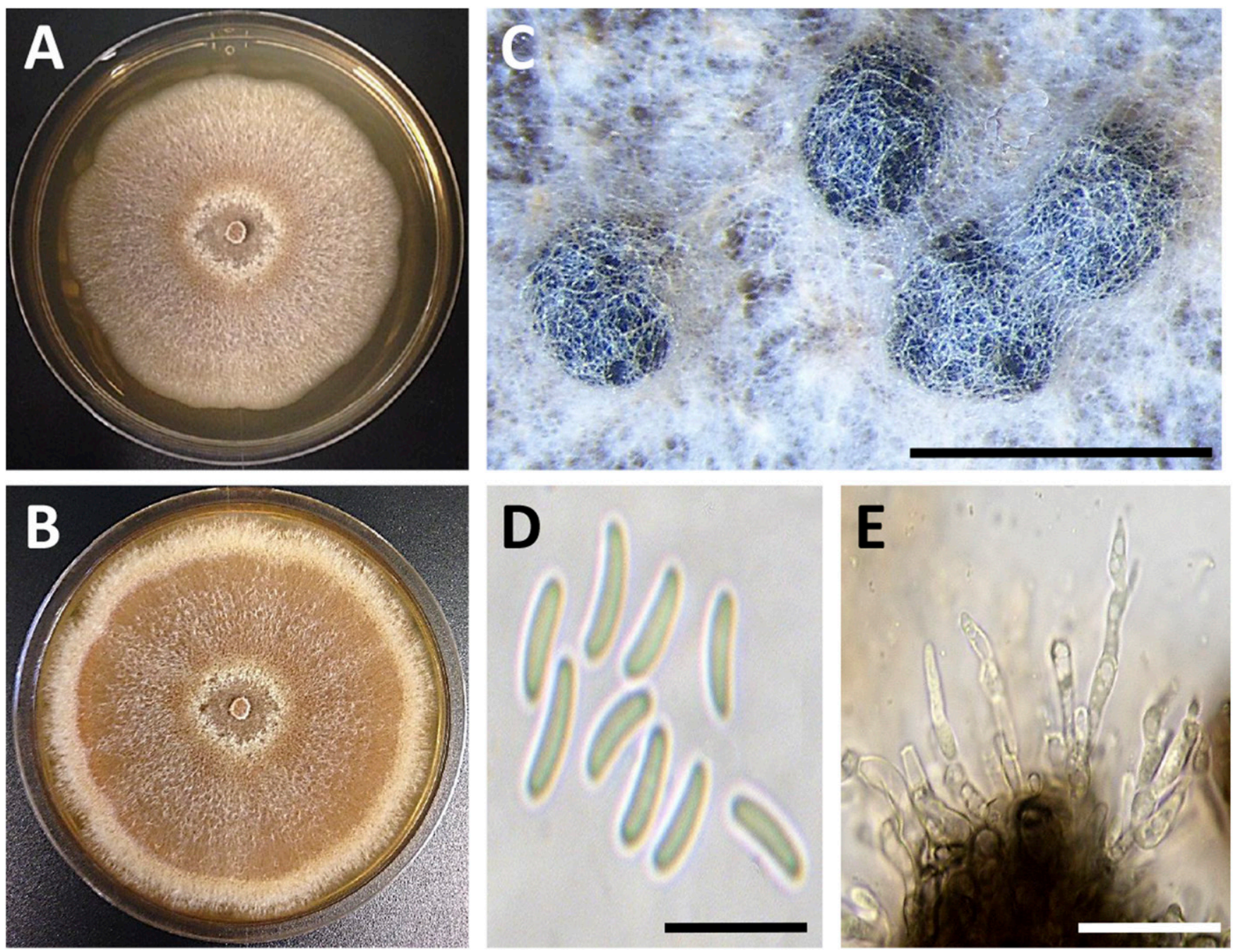

Fig. 3. Morphology of Cytospora olivarum UCD634-Oe, ex-type CBS 145585 . A, Colony cultured on potato dextrose agar at $25^{\circ} \mathrm{C}$ in the dark for 7 days. B, Colony cultured on potato dextrose agar at $25^{\circ} \mathrm{C}$ in the dark for 14 days. C, Pycnidia. D, Conidia. E, Conidiophores and filamentous conidiogenous cells. Scale bars: $1 \mathrm{~mm}$ (C), $5 \mu \mathrm{m}$ (D), and $20 \mu \mathrm{m}(\mathrm{E})$ 
UCD474-Oe, and KARE255 to KARE258), strongly nested (99\%/ 91\% MP and ML bootstrap values, respectively) within the clade containing the type specimen of C. oleicola CBS 144248 (Fig. 4). The other two representative isolates selected from the other morphological group (UCD634-Oe and UCD644-Oe) represented a single lineage $(100 \% / 98 \%)$ that was not closely associated with a type or non-type isolate with DNA sequence data and thus represents a novel species hereinafter identified as $C$. olivarum sp. nov. (Fig. 4).

Cytospora spp. incidence and distribution. Characterization of Cytospora sp. group one (C. oleicola) and Cytospora sp. group two $(C$. olivarum) in this study allowed us to determine their incidence and distribution in symptomatic olive trees in California

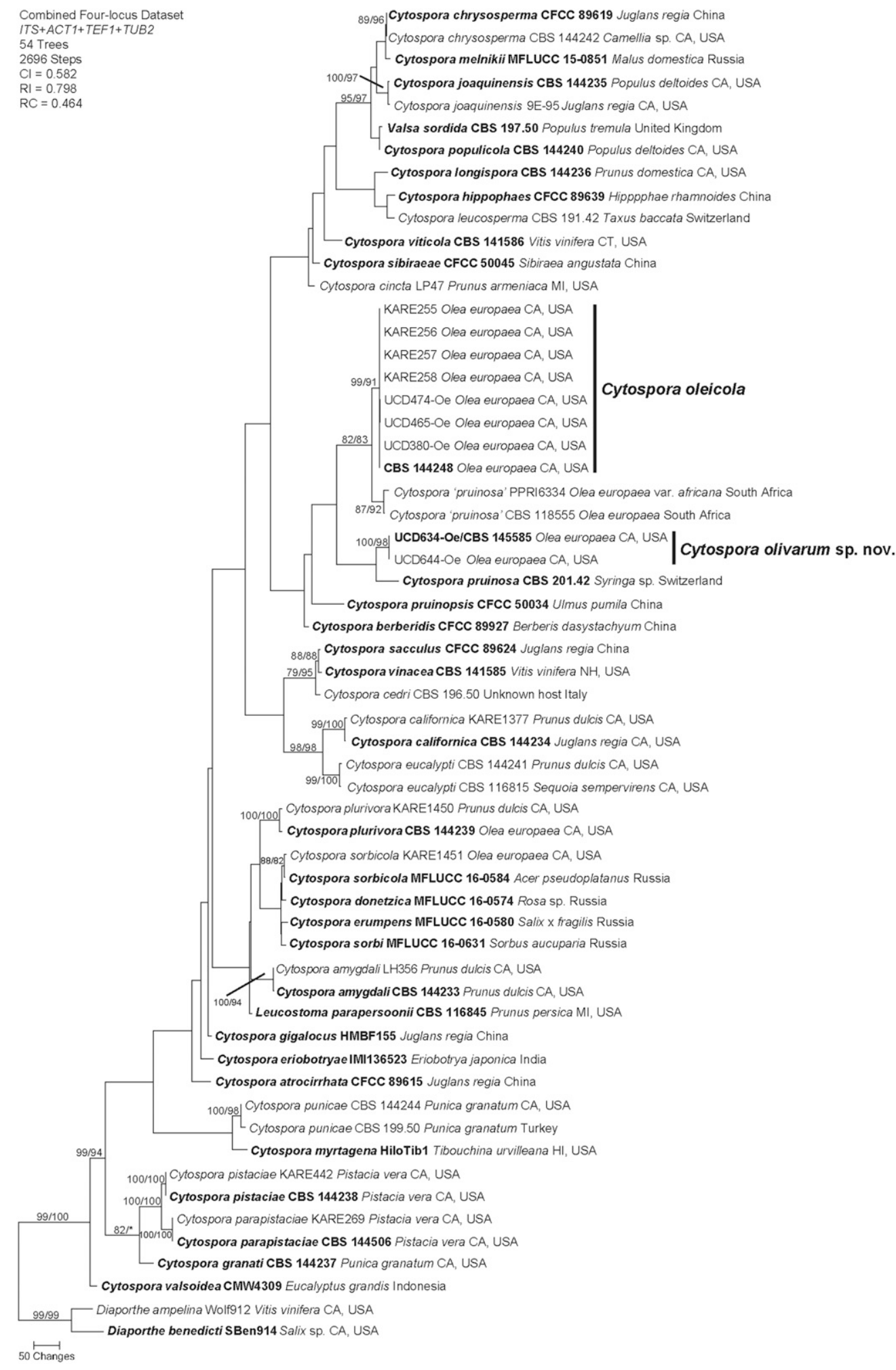

Fig. 4. One of 54 equally most parsimonious trees generated from maximum parsimony analysis of the four-gene (ITS, TEF1, TUB2, and ACT1) combined dataset. Numbers in front and after the slash represent parsimony and likelihood bootstrap values from 1,000 replicates, respectively. Values represented by an asterisk were less than $70 \%$ for the bootstrap analyses. Ex-type isolates are indicated in bold. Bar indicates the number of nucleotide changes. 
(Table 2) based on the field survey data collected between 2008 and 2009 (Úrbez-Torres et al. 2013). Cytospora was isolated from cankers in commercial olive orchards in the north and central coasts, the San Joaquin Valley, and Southern California in olive cvs. Ascolano, Manzanillo, Mission, and Sevillano. Riverside County followed by Ventura, Madera, and Tulare counties had the highest incidence of Cytospora isolated from cankers. No Cytospora was isolated from olive orchards in the Sacramento Valley. Cytospora was isolated from a very small number of twig dieback samples only in Napa, Fresno, and Merced counties (Table 2). C. oleicola was present in olive trees in Fresno, Madera, Merced, Napa, Riverside, Santa Barbara, Sonoma, Tulare, and Ventura counties. The new species $C$. olivarum was restricted to orchards in Ventura County in the Central Coast.

Pathogenicity tests. Mean lengths of vascular discoloration caused by $C$. oleicola isolate UCD465-Oe and $C$. olivarum isolate UCD634-Oe in 'Manzanillo' and 'Sevillano' were significantly longer than those in the mock-inoculated controls (Fig. 5). Six months after inoculation, symptoms observed on fungal inoculated branches included flattening of the bark and wedge-shaped cankers (in cross-section) in the xylem, similar to those observed on olive trees in the field (Fig. 5). Mock-inoculated controls expressed no external symptoms and had minimal discoloration extending from the inoculation site (average $1.4 \mathrm{~mm}$ ). C. olivarum caused slightly larger lesions, on average, than C. oleicola in 'Manzanillo' (28.4/25.1 mm) and 'Sevillano' $(29.3 / 24 \mathrm{~mm})$, respectively, but they were not statistically different $(P>0.05)$. C. oleicola and $C$. olivarum were reisolated from $100 \%$ of the inoculated branches in both cvs. No Cytospora-like fungi or other known fungal pathogens were reisolated from the mock-inoculated controls. 'Manzanillo' and 'Sevillano' showed no significant differences in susceptibility to $C$. oleicola or C. olivarum $(P>0.05)$.

\section{Discussion}

The present study identifies $C$. oleicola and $C$. olivarum sp. nov. from cankers in olive trees showing dieback symptoms in California. Completion of Koch's postulates showed that these species are pathogenic on olive.

Early phylogenetic studies on Cytospora have used the ITS1-5.8S-ITS2 gene region for species discrimination (Adams et al. 2002, 2005, 2006). In the present study, phylogenetic analysis of ITS alone could not confidently separate $C$. oleicola from two isolates illegitimately named $C$. 'pruinosa;' however, it strongly supported the newly described species $C$. olivarum (data not shown). The lack of phylogenetic resolution of the ITS region to separate fungal taxa has been broadly documented (Cabral et al. 2012; Inderbitzin et al. 2010; Úrbez-Torres 2011). Therefore, protein-coding genes have been utilized in multigene phylogenetic analyses to discriminate closely related Cytospora spp. (Lawrence et al. 2017, 2018). In the present study, the phylogenetic analysis of the TEF1 locus strongly supported both $C$. oleicola and C. olivarum (data not shown). The systematics of Cytospora spp. would greatly benefit from a consensus effort of sequencing similar loci and regions so that DNA data are comparable. It is recommended that taxonomic studies use the TEF1, $A C T 1$, and ITS regions using primers referenced in the present study when identifying Cytospora spp.

Species within the genus Cytospora have been well-studied as pathogens causing cankers, dieback and mortality of many woody plants including various fruit and nut trees such as peach, plum, cherry, apple, and almond (Farr and Rossman 2019; Trouillas et al. 2012). However, until the present study, little was known about $C y t o-$ spora spp. affecting olive. Mainly, C. oleina was identified as a pathogen of olive in Greece causing twig cankers and dieback (Rumbos 1988) and the same species also was pathogenic on pear, apple, quince, plum, sweet cherry, peach, and apricot. Most research efforts on fungal diseases affecting olive have focused on Neofabraea leaf and shoot lesions (olive leprosy), olive anthracnose, peacock spot, or Verticillium wilt, which usually cause rapidly developing symptoms that can be easily recognized by growers (Molina de la Rosa et al. 2017). Slowly progressing canker diseases become more apparent as trees age and often can be missed in the early stages of an orchard's life. This could explain why these pathogens have been overlooked in the past. Furthermore, Cytospora spp. have often been considered innocuous endophytes or weak/opportunistic pathogens infecting hosts through damage or wounds caused by other biotic or abiotic stressors (Christensen 1940).

In this study, we show for the first time the pathogenicity of C. oleicola and $C$. olivarum on olive trees. Both species were able to colonize the vascular tissue and produce symptoms including flattened outer bark, vascular necrosis, and wedge-shaped cankers similar to those observed in naturally infected fields. Six months after inoculation of branches in mature trees of cvs. Manzanillo and Sevillano, $C$.

Table 2. Incidence and distribution of Cytospora oleicola and C. olivarum associated with olive twig and branch dieback in California

\begin{tabular}{|c|c|c|c|c|c|c|}
\hline Region & County & $\begin{array}{l}\text { \# Orchards } \\
\text { surveyed }^{\mathrm{a}}\end{array}$ & $\begin{array}{l}\text { \# Cankers } \\
\text { collected }^{\mathrm{a}}\end{array}$ & $\begin{array}{c}\text { \# Cankers (\%) } \\
\text { yielding Cytospora }\end{array}$ & $\begin{array}{l}\text { \# Twig dieback } \\
\text { collected }\end{array}$ & $\begin{array}{c}\text { \# Twig dieback (\%) } \\
\text { yielding Cytospora }\end{array}$ \\
\hline \multirow[t]{7}{*}{ Sacramento Valley } & Butte & 6 & 62 & 0.0 & 11 & 0 \\
\hline & Glenn & 6 & 11 & 0.0 & 37 & 0 \\
\hline & Sacramento & 3 & 38 & 0.0 & 10 & 0 \\
\hline & Solano & 2 & 25 & 0.0 & - & - \\
\hline & Tehama & 3 & 25 & 0.0 & 10 & 0 \\
\hline & Yolo & 2 & 28 & 0.0 & - & - \\
\hline & Total & 22 & 189 & 0.0 & 68 & 0 \\
\hline \multirow[t]{3}{*}{ North Coast } & Napa & 5 & 28 & $2(7.1)$ & 31 & $9(29)$ \\
\hline & Sonoma & 3 & 53 & $3(5.6)$ & - & - \\
\hline & Total & 8 & 71 & $5(7.0)$ & 31 & $9(29)$ \\
\hline \multirow[t]{5}{*}{ San Joaquin Valley } & Fresno & 3 & 24 & $5(20.8)$ & 8 & $2(25)$ \\
\hline & Madera & 6 & 71 & $19(26.8)$ & - & - \\
\hline & Merced & 5 & 44 & $6(13.6)$ & 21 & $1(4.8)$ \\
\hline & Tulare & 4 & 55 & $14(25.5)$ & - & \\
\hline & Total & 18 & 194 & $44(22.7)$ & 29 & $3(10.3)$ \\
\hline \multirow[t]{3}{*}{ Central Coast } & Santa Barbara & 2 & 28 & $6(21.4)$ & - & - \\
\hline & Ventura & 5 & 58 & $16(27.6)^{\mathrm{b}}$ & - & - \\
\hline & Total & 7 & 86 & $22(25.5)$ & - & - \\
\hline Southern California & Riverside & 4 & 63 & $18(28.6)$ & - & - \\
\hline California & Total & 59 & 603 & $89(14.7)$ & 128 & $12(9.4)$ \\
\hline
\end{tabular}

a Data from Úrbez-Torres et al. (2013).

b Cytospora olivarum was isolated from cankers (13 isolates) only in Ventura County. 
oleicola and $C$. olivarum caused lesions that averaged $26.7 \mathrm{~mm}$ in length. When tested under similar experimental conditions, Neofusicoccum mediterraneum and Diplodia mutila produced lesions that averaged $68.9 \mathrm{~mm}$ and $59.8 \mathrm{~mm}$, respectively (Úrbez-Torres et al. 2013). This difference in lesion length could indicate a higher virulence for Botryosphaeriaceae fungi in olive, which are well known as aggressive canker pathogens of multiple woody plants worldwide (Úrbez-Torres 2011). Despite a relatively high incidence of Cytospora spp. in cankers as indicated by the present study, Botryosphaeriaceae fungi may be the most prevalent canker pathogens of olive in California (Úrbez-Torres et al. 2013). Although this was not investigated, $C$. oleicola and $C$. olivarum have been reported to be more virulent than other common canker pathogens of olive such as $B$. dothidea, D. seriata, E. lata, Schizophyllum commune, and Trametes versicolor (Moral et al. 2010, Úrbez-Torres et al. 2013).

Recently, Lawrence et al. (2018) investigated the taxonomy and phylogenetic diversity of Cytospora spp. associated with canker diseases of fruit and nut trees in California and identified 15 different species, including C. oleicola, C. plurivora, and C. sorbicola from olive. Although no pathogenicity tests were conducted, Lawrence et al. (2018) found an association between Cytospora spp. and olive cankers. The same authors reported C. oleicola and C. plurivora from olive trees in San Joaquin County and C. sorbicola from Kings County in California (Lawrence et al. 2018). Our study largely expands the known geographical distribution of $C$. oleicola, which appears to be the most common and widespread Cytospora spp. associated with olive tree dieback in California. Interestingly, neither C. olivarum nor C. oleicola was found from olive orchards in the Sacramento Valley, including Butte, Glenn, and Tehama counties, which represent an important olive-growing region. We hypothesize that

A
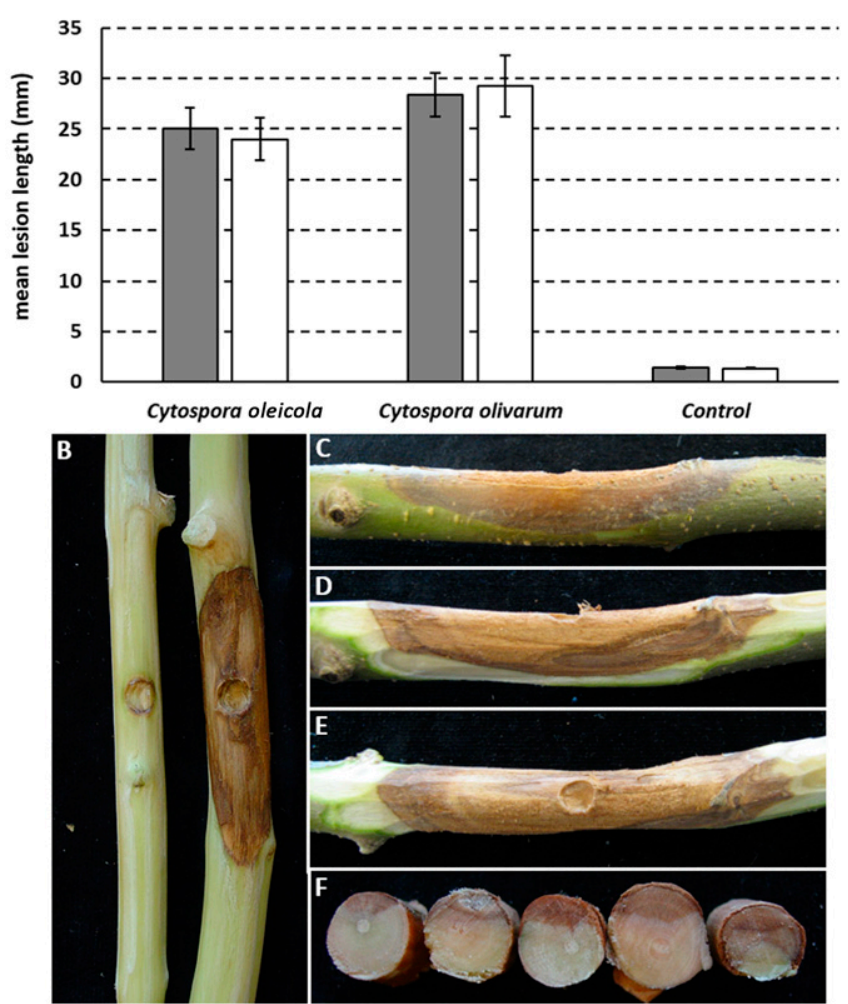

Cytospora oleicola

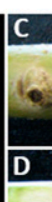

Control
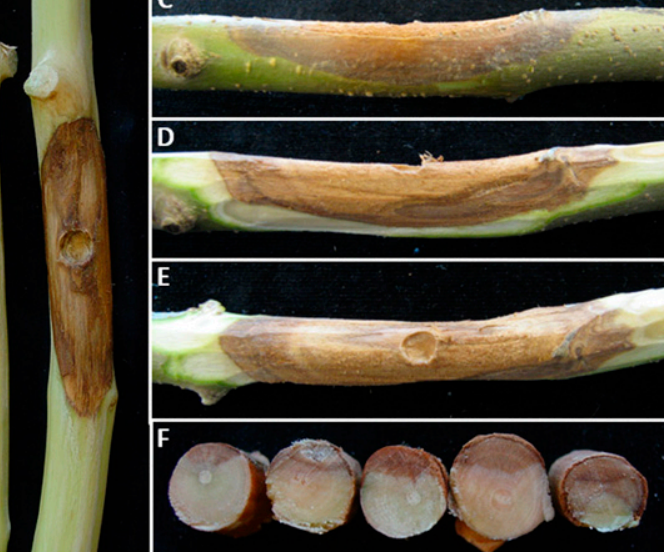

Fig. 5. Pathogenicity test of Cytospora oleicola UCD465-Oe and Cytospora olivarum UCD674-Oe in 'Manzanillo' and 'Sevillano' olive. A, Mean lesion length caused by $C$. oleicola and C. olivarum in 'Manzanillo' and 'Sevillano' 6 months after inoculation. Bars represent standard error of the mean. B, Canker caused by C. oleicola UCD474-Oe in a 'Manzanillo' 2- to 3-year-old branch 6 months after inoculation compared with mock inoculated control. C to F, Symptoms caused by $C$. olivarum UCD674-Oe in a 'Manzanillo' branch 6 months after inoculation. Flat and sunken area and wedgeshaped cankers that developed were similar to those observed in naturally infected olive trees in the field. environmental conditions such as temperature and relative humidity likely influence the geographic distribution of $C$. olivarum and $C$. oleicola, which may favor the hot and dry weather of Southern California, rather than the cooler and more humid climate of the Sacramento Valley. Also, this could be the result of a reduced host range and lack of susceptible hosts to $C$. olivarum and $C$. oleicola in these northern counties. Indeed, $C$. oleicola has been reported so far only from olive, which suggests it is specific to this host. Interestingly, C. plurivora and $C$. sorbicola previously reported from olive and several other hosts in California, including fruit and nut trees (Lawrence et al. 2018) were not found in our study.

The current study showed that $C$. oleicola and $C$. olivarum play an important role in the etiology of olive branch and twig dieback in California. However, most trees sampled during this study occurred in mature, low density olive orchards used primarily for the production of table olives. The occurrence of C. oleicola and C. olivarum in SHD orchards was not investigated despite a recent increase of SHD plantings. However, mechanized practices in SHD orchards can cause severe damage to the bark and wood of trunks and branches of olive trees, allowing infection by fungal pathogens (Trouillas et al. 2019). Mechanical pruning results in multiple cuts on trees, which greatly surpass the amount of pruning wounds produced in traditionally farmed low-density orchards, where pruning generally occurs every 2 years. Accordingly, research needs to investigate the impact of mechanized practices in SHD systems on infection by Cytospora spp. and other fungal canker pathogens.

Rumbos (1988) showed that fall inoculation of olive twigs with $C$. oleina caused much longer lesions than spring inoculations using the same isolate. In California SHD orchards, wounds are produced from mechanical harvests that occur in the fall, which may contribute to infection by Cytospora spp. Using funnel traps attached to fruit trees, Bertrand and English (1976) showed that conidia of C. leucostoma were wind-blown during fall and winter rainfalls in California and could travel up to $76.8 \mathrm{~m}$ from the inoculum source. A similar study conducted by Cujec (1985) in the fruit tree region of the Okanagan Valley in British Columbia showed that Cytospora spores were released throughout the rainy periods from early spring until the freeze-up in November. With the availability of automated spore trapping devices and absolute molecular quantification of the target pathogen (Billones-Baaijens et al. 2018; Úrbez-Torres et al. 2017), spore trapping studies in olive orchards in California would contribute to a better understanding of the seasonal production and dispersal of Cytospora inoculum. Spore trapping studies combined with studies evaluating the effectiveness of pruning wound protectants as well as the seasonal susceptibility of pruning wound to Cytospora spp. could support the development of effective control strategies.

\section{Acknowledgments}

We thank University of California Cooperative Extension Farm Advisors J. H. Connell (UCCE Butte County), C. A. Ingles (UCCE Sacramento County), D. Doll (UCCE Merced County), N. V. O'Connell (UCCE Tulare County), and B. Faber (UCCE Ventura County) for their valuable assistance and guidance in accomplishing the field collections between 2008 and 2009.

\section{Literature Cited}

Adams, G. C., Roux, J., and Wingfield, M. J. 2006. Cytospora species (Ascomycota, Diaporthales, Valsaceae): introduced and native pathogens of trees in South Africa. Australas. Plant Pathol. 35:521-548.

Adams, G. C., Surve-Iyer, R. S., and Iezzoni, A. F. 2002. Ribosomal DNA sequence ivergence and group I introns within the Leucostoma species $L$. cinctum, $L$. persoonii, and $L$. parapersoonii sp. nov., ascomycetes that cause Cytospora canker of fruit trees. Mycologia 94:947-967.

Adams, G. C., Wingfield, M. J., Common, R., and Roux, J. 2005. Phylogenetic relationships and morphology of Cytospora species and related teleomorphs (Ascomycota, Diaporthales, Valsaceae) from Eucalyptus. Stud. Mycol. 52 $1-144$.

Alves, A., Crous, P. W., Correia, A., and Phillips, A. 2008. Morphological and molecular data reveal cryptic speciation in Lasiodiplodia theobromae. Fungal Divers. 28:1-13.

Bertrand, P. F., and English, H. 1976. Release and dispersal of conidia of Valsa leucostoma. Phytopathology 66:987-991.

Billones-Baaijens, R., Úrbez-Torres, J. R., Liu, M., Ayres, M., Sosnowski, M., and Savocchia, S. 2018. Molecular methods to detect and quantify Botryosphaeriaceae inocula causing grapevine dieback in Australia. Plant Dis. 102:1489-1499. 
Bills, G. F. 1996. Isolation and Analysis of Endophytic Fungal Communities from Woody Plants. American Phytopathological Society Press, St Paul, MN.

Cabral, A., Groenewald, Z. J., Rego, C., Oliveira, H., and Crous, P. W. 2012. Cylindrocarpon root rot: Multi-gene analysis reveals novel species within the Ilyonectria radicicola species complex. Mycol. Prog. 11:655-688.

Carbone, I., and Kohn, L. M. 1999. A method for designing primer sets for speciation studies in filamentous ascomycetes. Mycologia 91:553-556.

Chattaoui, M., Rhouma, A., Krid, S., Ali Triki, M., Moral, J., Msallem, M., and Trapero, A. 2011. First report of fruit rot of olives caused by Botryosphaeria dothidea in Tunisia. Plant Dis. 95:770.

Christensen, C. M. 1940. Studies on the biology of Valsa sordida and Cytospora chrysosperma. Phytopathology 30:459-475.

Cujec, T. P. 1985. Incidence, etiology and epidemiology of stone fruit dieback in the Okanagan Valley. MSc Thesis dissertation. The University of British Columbia, Vancouver

Farr, D. F., and Rossman, A. Y. 2019. Fungal Databases, Systematic Mycology and Microbiology Laboratory, ARS, USDA. Retrieved 15 August 2019 from: https://nt.ars-grin.gov/fungaldatabases/

Food and Agriculture Organization of the United Nations (FAO). FAOSTAT (C) FAO Statistics Division. Retrieved 1 September 2019 from http://faostat. fao.org/default.aspx

Glass, N. L., and Donaldson, G. C. 1995. Development of primer sets designed for use with the PCR to amplify conserved genes from filamentous Ascomycetes. Appl. Environ. Microbiol. 61:1323-1330.

Inderbitzin, P., Bostock, R. M., Trouillas, F. P., and Michailides, T. J. 2010. A six locus phylogeny reveals high species diversity in Botryosphaeriaceae from California almond. Mycologia 102:1350-1368.

Kaliterna, K., Ivic, I., Bencic, D., and Mesic, A. 2012. First report of Diplodia seriata as causal agent of olive dieback in Croatia. Plant Dis. 96:290.

Kirk, P. M., Cannon, P. F., Minter, D. W. and Stalpers, J. A., eds. 2008. Ainsworth $\&$ Bisby's Dictionary of the Fungi. 10th ed. CAB International, Wallingford, U.K.

Lawrence, D. P., Holland, L. A., Nouri, M. T., Travadon, R., Abramians, A., Michailides, T. J., and Trouillas, F. P. 2018. Molecular phylogeny of Cytospora species associated with canker diseases of fruit and nut crops in California, with the descriptions of ten new species and one new combination. IMA Fungus 9:333-369.

Lawrence, D. P., Travadon, R., and Baumgartner, K. 2015. Diversity of Diaporthe species associated with wood cankers of fruit and nut crops in Northern California. Mycologia 107:926-940.

Lawrence, D. P., Travadon, R., Pouzoulet, J., Rolshausen, P., Wilcox, W., and Baumgartner, K. 2017. Characterization of Cytospora isolates from wood cankers of declining grapevine in North America, with the descriptions of two new Cytospora species. Plant Pathol. 66:713-725.

Lazicki, P., and Geisseler, D. 2016. Olive production in California. Available online at https://apps1.cdfa.ca.gov/FertilizerResearch/docs/Olive_Production_ CA.pdf

Maddison, W. P., and Maddison, D. R. 2016. MESQUITE: a modular system for evolutionary analysis. Version 3.10. http://www.mesquiteproject.org.

Malathrakis, N. E. 1979. Studies on a disease of olive due to fungus Phoma incompta Sacc. \& Mart. Ph.D. dissertation, University of Athens, Greece.

Molina de la Rosa, J. L., Jiménez Herrera, B., Ruiz Coleto, F., García Zamorano, F., Cano Rodríguez, J., and Pérez García, J. 2017. Técnicas de cultivo: Plagas y enfermedades del olivo. Viceconsejería, Servicio de Publicaciones y Divulgación. J. de Andalucía, ed. Consejería de Agricultura y Pesca, Sevilla, Spain
Moral, J., Muñoz-Díez, C., González, N., Trapero, A., and Michailides, T. 2010. Characterization and pathogenicity of Botryosphaeriaceae species collected from olive and other hosts in Spain and California. Phytopathology 100: 1340-1351

Rayner, R. W. 1970. A mycological colour chart. Commonwealth Mycological Institute \& British Mycological Society, Kew, Surrey, England.

Romero, M. A., Sánchez, M. E., and Trapero, A. 2005. First report of Botryosphaeria ribis as a branch dieback pathogen of olive trees in Spain. Plant Dis. 89:208.

Rumbos, I. C. 1988. Cytospora oleina causing canker and dieback of olive in Greece. Plant Pathol. 37:441-444.

Rumbos, I. C. 1993. Dieback symptoms on olive trees caused by the fungus Eutypa lata. Bull. OEPP/EPPO Bull. 23:441-445.

Schroth, M. N., and Osgood, J. W. 1971. Relationship between the olive knot disease and reduced yield. Calif. Olive Ind. News 25, no. 1 (February).

Swofford, D. L. 1999. PAUP*. Phylogenetic Analysis Using Parsimony (*and other methods), version 4.0b4a. Sinauer Associates, Sunderland, MA.

Tamura, K., Stecher, G., Peterson, D., Filipski, A., and Kumar, S. 2013. MEGA6: Molecular evolutionary genetics analysis version 6.0. Mol. Biol. Evol. 30: 2725-2729.

Taylor, R. K., Hale, C. N., and Hartill, W. F. T. 2001. A stem canker disease of olive (Olea europaea) in New Zealand. N. Zeal. J. Crop Hortic. 29:219-228.

Teviotdale, B. L. 2005. Diseases of olive. Pages119-121 in: Olive Production Manual, Second Edition. G. S. Sibbett and L. Ferguson, eds. University of California Agricultural and Natural Resources, Publication 3353, Oakland, CA.

Tosi, L., and Natalini, G. 2009. First report of Eutypa lata causing dieback of olive trees in Italy. Plant Pathol. 58:398.

Tous, J., Romero, A., Hermoso, J. F., and Ninot, A. 2011. Mediterranean clonal selections evaluated for modern hedgerow olive oil production in Spain. Calif. Agric. 65:34-40.

Trouillas, F. P., Nouri, M. T., Lawrence, D. P., Moral, J., Travadon, R., Aegerter B. J., and Lightle, D. 2019. Identification and characterization of Neofabraed kienholzii and Phlyctema vagabunda causing leaf and shoot lesions of olive in California. Plant Dis. 103:3018-3030.

Trouillas, F. P., Peduto, F., Lorber, J. D., Sosnowski, M. R., Grant, J., Coates, W. W., Anderson, K. K., Caprile, J., and Gubler, W. D. 2012. Calosphaeria canker of sweet cherry caused by Calosphaeria pulchella in California and South Australia. Plant Dis. 96:648-658.

Úrbez-Torres, J. R. 2011. The status of Botryosphaeriaceae species infecting grapevines. Phytopathol. Mediterr. 50:5S-44S.

Úrbez-Torres, J. R., Peduto, F., Vossen, P. M., Krueger, W. H., and Gubler, W. D. 2013. Olive twig and branch dieback: etiology, incidence and distribution in California. Plant Dis. 97:231-244.

Úrbez-Torres, J. R., Walker, M., Boule, J., and O'Gorman, D. T. 2017. Grapevine trunk diseases epidemiological studies in British Columbia: implementation of droplet digital PCR. Phytopathol. Mediterr. 56:541-542.

Vossen, P. M. 2007. Olive oil: history, production, and characteristics of the world's classic oils. HortScience 42:1093-1100.

White, T. J., Bruns, T., Lee, S., and Taylor, J. 1990. Amplification and direct sequencing of fungal ribosomal RNA genes for phylogenetics. Pages 315-322 in: PCR Protocols, A Guide to Methods and Applications. M. A. Innis, D. H Gelfand, J. J. Sninsky, and T. J. White, eds. Academic Press, San Diego, CA.

Zwickl, D. J. 2006. Genetic algorithm approaches for the phylogenetic analysis of large biological sequence datasets under the maximum likelihood criterion. Ph.D. dissertation. Department of Integrative Biology, University of TexasAustin, U.S.A 